\title{
Hemipristicola gunterae gen. n., sp. n. (Cestoda: Tetraphyllidea: Phyllobothriidae) from the snaggletooth shark, Hemipristis elongata (Carcharhiniformes: Hemigaleidae), from Moreton Bay, Australia
}

\author{
Scott C. Cutmore ${ }^{1,2}$, Susan M. Theiss ${ }^{3}$, Michael B. Bennett ${ }^{2}$ and Thomas H. Cribb ${ }^{1}$ \\ ${ }^{1}$ School of Biological Sciences, The University of Queensland, Brisbane, Queensland 4072, Australia; \\ ${ }^{2}$ School of Biomedical Sciences, The University of Queensland, Brisbane, Queensland 4072, Australia; \\ ${ }^{3}$ School of Geography, Planning and Environmental Management, The University of Queensland, Brisbane, Queensland 4072, \\ Australia
}

\begin{abstract}
Helminthological examination of the snaggletooth shark, Hemipristis elongata (Klunzinger) (Carcharhiniformes: Hemigaleidae), from Moreton Bay, Queensland, Australia, yielded a phyllobothriid genus and species previously unknown to science. Hemipristicola gunterae gen. n., sp. n. is described here, and is placed in the subfamily Phyllobothriinae Braun, 1900. Of the other phyllobothriid genera, the new genus most closely resembles Paraorygmatobothrium in that both genera possess bothridia with a single loculus and apical sucker, post-vaginal testes and lateral vitellarium. Hemipristicola, however, differs from Paraorygmatobothrium in the morphology of the proximal bothridial surface microthrix, possessing serrate gladiate spinitriches with marginal serrations restricted to the distal half of the blade, and in the possession of a more extensive uterus, extending anteriorly from the anterior margin of the ovary to well past the level of the cirrus-sac. The new genus also differs from Paraorygmatobothrium by possessing testes that are more than one layer deep. Hemipristicola gunterae further differs from Paraorygmatobothrium species found in hemigaleid sharks in possessing vitelline follicles arranged in two lateral bands that are restricted to the lateral margins of the proglottid and not possessing a cephalic peduncle. Bayesian inference analysis of partial 28S rDNA data shows that $H$. gunterae forms a sister taxon to species of Paraorygmatobothrium. These two genera were resolved with high posterior probability support in the analysis. Hemipristicola gunterae is only the second phyllobothriid species to be described from Hemipristis elongata from Australian waters, and the fourth from the Australian hemigaleids.
\end{abstract}

Keywords: Tetraphyllidea, Phyllobothriidae, Phyllobothriinae, Hemipristicola gunterae, Hemigaleidae, Hemipristis elongata, Australia, Moreton Bay

During helminthological examinations of carcharhiniform sharks of Moreton Bay, Queensland, Australia, two specimens of the snaggletooth shark, Hemipristis elongata (Klunzinger), were examined for tetraphyllidean cestodes. Hemipristis elongata (Hemigaleidae) is a relatively uncommon elasmobranch species in Moreton Bay, with only five collections recorded there to date. It is more commonly encountered in tropical Indo-West Pacific waters, where it inhabits continental and insular shelves and feeds on cephalopods, teleosts and other elasmobranchs (Last and Stevens 2009). To date only three tetraphyllidean species have been described from H. elongata in Australian waters. Ruhnke et al. (2006a) described Paraorygmatobothrium janineae Ruhnke, Healy et Shapero, 2006 from H. elongata from three locations off the Northern Territory, Australia, which was subsequently recorded from Moreton Bay, Queensland by Cutmore et al. (2009). The remaining two species belong to the onchobothriid genus Megalonchos Baer et Euzet, 1962. Caira et al. (2007) described Megalonchos sumansinghai Caira, Reyda et Mega, 2007 and M. shawae Caira, Reyda et Mega, 2007 from the Arafura Sea off the Northern Territory. Both individuals of $H$. elongata collected during this study were infected by at least three species of tetraphyllideans, including a phyllobothriid genus and species previously unknown to science. The new genus and species is described here and relationships with other phyllobothriid genera are discussed.

\section{MATERIALS AND METHODS}

Specimen collection and preparation. Two specimens of Hemipristis elongata were collected from Moreton Bay, Queensland in February, 2007. Spiral intestines were removed and kept on ice ( $<4$ hours) for transport prior to examination. Spiral intestines were opened longitudinally and examined under a dissecting microscope. Cestodes were removed, washed 
Table 1. Number of sequence replicates and GenBank accession numbers for 28S rDNA sequences of Hemipristicola gen. n. and Paraorygmatobothrium produced during this study.

\begin{tabular}{|c|c|c|c|c|c|}
\hline Species & Host species & Location & $\begin{array}{l}\text { Replicates } \\
\text { generated/ } \\
\text { submitted }\end{array}$ & $\begin{array}{l}\text { GenBank ac- } \\
\text { cession No. }\end{array}$ & $\begin{array}{l}\text { Morphological } \\
\text { voucher No. }\end{array}$ \\
\hline Hemipristicola gunterae gen. n., sp. n. & $\begin{array}{l}\text { Hemipristis } \\
\text { elongata }\end{array}$ & $\begin{array}{l}\text { Wynnum banks }\left(27^{\circ} 25^{\prime} \mathrm{S} ; 153^{\circ} 10^{\prime} \mathrm{E}\right) \text {, } \\
\text { Moreton Bay, Queensland, Australia }\end{array}$ & $3 / 3$ & HQ680622-4 & QM G 232173-81 \\
\hline $\begin{array}{l}\text { Paraorygmatobothrium janineae } \\
\text { Ruhnke, Healy et Shapero, } 2006\end{array}$ & $\begin{array}{l}\text { Hemipristis } \\
\text { elongata }\end{array}$ & $\begin{array}{l}\text { Wynnum banks }\left(27^{\circ} 25^{\prime} \mathrm{S} ; 153^{\circ} 10^{\prime} \mathrm{E}\right) \text {, } \\
\text { Moreton Bay, Queensland, Australia }\end{array}$ & $6 / 3$ & HQ680625-7 & QM G 231309-14 \\
\hline $\begin{array}{l}\text { Paraorygmatobothrium paulum } \\
\text { (Linton, 1897) Ruhnke, } 2011\end{array}$ & $\begin{array}{l}\text { Galeocerdo } \\
\text { cuvier }\end{array}$ & $\begin{array}{l}\text { off St. Helena Island }\left(27^{\circ} 22^{\prime} \mathrm{S} ; 153^{\circ} 11^{\prime} \mathrm{E}\right) \text {, } \\
\text { Moreton Bay, Queensland, Australia }\end{array}$ & $5 / 3$ & HQ680628-30 & QM G 232182-203 \\
\hline $\begin{array}{l}\text { Paraorygmatobothrium taylori } \\
\text { Cutmore, Bennett et Cribb, } 2009\end{array}$ & $\begin{array}{l}\text { Hemigaleus } \\
\text { australiensis }\end{array}$ & $\begin{array}{l}\text { off St. Helena Island }\left(27^{\circ} 22^{\prime} \mathrm{S} ; 153^{\circ} 11^{\prime} \mathrm{E}\right) \text {, } \\
\text { Moreton Bay, Queensland, Australia }\end{array}$ & $8 / 3$ & HQ680631-3 & QM G 231303-7 \\
\hline
\end{tabular}

and subsequently killed in near-boiling vertebrate saline $(0.85 \%$ $\mathrm{NaCl}$ solution). Worms were then fixed in either $10 \%$ formalin, for morphological examination and scanning electron microscopy (SEM), or in $100 \%$ ethanol for molecular analysis. Due to the limited number of Hemipristicola specimens collected, some worms were fixed for both morphological and molecular analysis. For these specimens the anterior two-fifths and posterior two-fifths of the specimen were fixed in $10 \%$ formalin and the middle fifth in $100 \%$ ethanol.

Morphological analysis. Specimens for morphological examination were washed in freshwater, overstained in Mayer's haematoxylin, destained in a solution of $1.0 \% \mathrm{HCl}$ and neutralised in $0.5 \%$ ammonium hydroxide solution. Specimens were then dehydrated in a graded ethanol series, cleared in methyl salicylate and mounted in Canada balsam. Measurements were made using a SPOT Insight ${ }^{\mathrm{TM}}$ digital camera (Diagnostic Instruments, Inc.) mounted on an Olympus $\mathrm{BH}-2$ compound microscope using SPOT ${ }^{\mathrm{TM}}$ imaging software. Measurements are in micrometres unless otherwise stated and are given as the range followed in parentheses by the mean, standard deviation, number of worms measured, and the total number of measurements taken if multiple measurements were taken per worm. Drawings were made with the aid of a drawing tube. Microthrix terminology follows that of Chervy (2009).

SEM analysis. Specimens for SEM were dehydrated in a graded ethanol series, transferred to hexamethyldisilazane (HMDS) and allowed to air-dry overnight. Specimens were mounted on carbon tab pin stubs, sputter-coated with $20-30 \mathrm{~nm}$ of platinum (EIKO IB-5 Ion Coater, EIKO Engineering Company, Ibaraki, Japan) and stored with silica gel to absorb any residual moisture. Specimens were examined using either a JEOL JSM-6300F or a JSM-6610 scanning electron microscope (JEOL Ltd, Tokyo, Japan).

DNA sequencing. Tetraphyllidean species sequenced in this study are listed in Table 1. Total genomic DNA was extracted using phenol/chloroform extraction techniques (Sambrook and Russell 2001). The D1-D3 regions of the 28S nuclear ribosomal DNA region were amplified using the primers LSU5 (5'-TAG GTC GAC CCG CTG AAY TTA AGC-3') (Littlewood et al. 2000) and 1200R (5'-GCA TAG TTC ACC ATC TTT CGG-3') (Littlewood et al. 2000). PCR was performed with a total volume of $20 \mu \mathrm{l}$ consisting of approximately $10 \mathrm{ng}$ of DNA, $1.6 \mu \mathrm{l}$ of $\mathrm{MgCl}_{2}$ (Promega), $2 \mu \mathrm{l}$ of $10 \times$ reaction buffer (Promega), $0.8 \mu \mathrm{l}$ of deoxyribonucleotide triphosphate (dNTP) (each $2.5 \mathrm{mM}), 0.75 \mu \mathrm{l}$ of each primer $(10$ pmols) and $0.25 \mu 1$ of Taq DNA polymerase (Promega GoTaq ${ }^{\circledR}$ Flexi DNA Polymerase), made up to $20 \mu \mathrm{l}$ with Invitrogen ${ }^{\mathrm{TM}}$ ultraPURETM distilled water. Amplification was carried out on a MJ Research
PTC-150 thermocycler using the following profile: an initial $95^{\circ} \mathrm{C}$ denaturation for $4 \mathrm{~min}$, followed by 30 cycles of $95^{\circ} \mathrm{C}$ denaturation for $1 \mathrm{~min}, 56^{\circ} \mathrm{C}$ annealing for $1 \mathrm{~min}, 72^{\circ} \mathrm{C}$ extension for $2 \mathrm{~min}$, followed by a single cycle of $95^{\circ} \mathrm{C}$ denaturation for $1 \mathrm{~min}, 55^{\circ} \mathrm{C}$ annealing for $45 \mathrm{sec}$ and a final $72^{\circ} \mathrm{C}$ extension for $4 \mathrm{~min}$. Amplified DNA was purified using a QIAGEN ${ }^{\circledR}$ QIAquick ${ }^{\circledR}$ PCR purification kit, according to the manufacturer's protocol. Cycle sequencing of purified DNA was carried out using ABI Big Dye ${ }^{\mathrm{TM}}$ V.3.1 chemistry following the manufacturer's recommendations, using the same primers used for PCR amplification as well as the additional 28S rDNA primers 300F (5'-CAA GTA CCG TGA GGG AAA GTT-3') (Littlewood et al. 2000) and ECD2 (5'-CTT GGT CCG TGT TTC AAG ACG GG-3') (Littlewood et al. 2000). Cycle sequencing was carried out on a MJ Research PTC-150 thermocycler. Products were precipitated in $1 \mu \mathrm{l}$ of $3 \mathrm{M}$ sodium acetate $(\mathrm{pH} 5)$ and $25 \mu \mathrm{l}$ of $100 \%$ ethanol and the pellets dried for $30 \mathrm{~min}$ at $39^{\circ} \mathrm{C}$. Precipitated products were sequenced using an AB3730xl capillary sequencer at the Australian Genome Research Facility in Brisbane. Sequencher ${ }^{\mathrm{TM}}$ version 4.5 (GeneCodes Corp.) was used to assemble and edit contiguous sequences.

Phylogenetic analysis. The partial 28S rDNA sequences generated for Hemipristicola gunterae and Paraorygmatobothrium species (Table 1) were aligned with cestode taxa from the orders Lecanicephalidea, Rhinebothriidea and Tetraphyllidea (Table 2) using MUSCLE version 3.7 (Edgar 2004) with ClustalW sequence weighting and UPGMA clustering for iterations 1 and 2. The resultant alignments were refined by eye using MESQUITE (Maddison and Maddison 2009). After the alignment of the 28S dataset was edited, the ends of each fragment were trimmed to match the shortest sequence in the alignment.

Bayesian inference analysis of the 28S rDNA dataset was performed using MrBayes version 3.1.2 (Ronquist and Huelsenbeck 2003) run on the CIPRES portal (Miller et al. 2009) to explore relationships among these taxa. The software jModelTest version 0.1.1 (Guindon and Gascuel 2003, Posada 2008) was used to estimate the best nucleotide substitution model for this dataset. Bayesian inference analysis was conducted on the $28 \mathrm{~S}$ rDNA dataset using the GTR $+\mathrm{G}$ model predicted (gamma distribution $=0.382$ ) as the best estimator by both the Akaike Information Criterion (AIC) and Bayesian Information Criterion (BIC) in jModelTest. Bayesian inference analysis was run over 10,000,000 generations (ngen $=10000000$ ) with two runs each containing four simultaneous Markov Chain Monte Carlo $(\mathrm{MCMC})$ chains (nchains $=4)$ and every 1000th tree saved (samplefreq $=1000$ ). Bayesian analyses used the following parameters: $n s t=6$, rates $=$ gamma, ngammacat $=4$, and the priors parameters of the combined dataset were set to ratepr $=$ vari- 
Table 2. 28S rDNA sequences from GenBank included in this study.

\begin{tabular}{|c|c|c|c|}
\hline Species & Host species & $\begin{array}{l}\text { GenBank } \\
\text { accession No. }\end{array}$ & Reference \\
\hline \multicolumn{4}{|l|}{ Order Lecanicephalidea } \\
\hline Adelobothrium cf. aetiobatidis Shipley, 1900 & Aetobatus narinari & EF095257 & Waeschenbach et al. 2007 \\
\hline Cephalobothrium aetobatidis Shipley et Hornell, 1906 & Aetobatus narinari & AF286927 & Olson et al. 2001 \\
\hline Eniochobothrium gracilis Shipley et Hornell, 1906 & Rhinoptera sp. & AF286928 & Olson et al. 2001 \\
\hline Eniochobothrium sp. & Rhinoptera bonasus & GQ470202 & Jensen and Bullard 2010 \\
\hline Polypocephalus sp. MS05-50-17 & Dasyatis say & GQ470199 & Jensen and Bullard 2010 \\
\hline Polypocephalus sp. MS05-50-18 & Dasyatis say & GQ470200 & Jensen and Bullard 2010 \\
\hline Tylocephalum sp. & Dasyatis sp. & AF286929 & Olson et al. 2001 \\
\hline \multicolumn{4}{|l|}{ Order Rhinebothriidea } \\
\hline Rhabdotobothrium anterophallum Campbell, 1975 & Mobula hypostoma & GQ470179 & Jensen and Bullard 2010 \\
\hline Rhinebothrium sp. 3 & Dasyatis say & GQ470190 & Jensen and Bullard 2010 \\
\hline Rhinebothrium sp. 4 & Dasyatis say & GQ470197 & Jensen and Bullard 2010 \\
\hline Rhodobothrium paucitesticulare Mayes et Brooks, 1981 & Rhinoptera bonasus & GQ470174 & Jensen and Bullard 2010 \\
\hline Spongiobothrium sp. MS05-253-6 & Dasyatis sabina & GQ470184 & Jensen and Bullard 2010 \\
\hline Spongiobothrium sp. MS05-253-7 & Dasyatis sabina & GQ470185 & Jensen and Bullard 2010 \\
\hline \multicolumn{4}{|l|}{ Order Tetraphyllidea } \\
\hline Dioecotaenia campbelli Mayes et Brooks, 1981 & Rhinoptera bonasus & GQ470156 & Jensen and Bullard 2010 \\
\hline \multicolumn{4}{|l|}{ Family Onchobothriidae Braun, 1900} \\
\hline Acanthobothrium sp. 6A & Dasyatis say & GQ470111 & Jensen and Bullard 2010 \\
\hline Acanthobothrium sp. 6B & Dasyatis say & GQ470112 & Jensen and Bullard 2010 \\
\hline Acanthobothrium sp. $6 \mathrm{C}$ & Dasyatis say & GQ470113 & Jensen and Bullard 2010 \\
\hline Phoreiobothrium sp. 1A & Carcharhinus brevipinna & GQ470082 & Jensen and Bullard 2010 \\
\hline Phoreiobothrium sp. 1B & Carcharhinus isodon & GQ470080 & Jensen and Bullard 2010 \\
\hline Phoreiobothrium sp. $1 \mathrm{C}$ & Carcharhinus limbatus & GQ470094 & Jensen and Bullard 2010 \\
\hline Phoreiobothrium sp. 1D & Rhizoprionodon terraenovae & GQ470073 & Jensen and Bullard 2010 \\
\hline Triloculatum bullardi Caira et Jensen, 2009 & Carcharhinus brevipinna & GQ470102 & Jensen and Bullard 2010 \\
\hline \multicolumn{4}{|l|}{ Family Phyllobothriidae Braun, 1900} \\
\hline \multicolumn{4}{|l|}{ Subfamily Phyllobothriinae Braun, 1900} \\
\hline Anthobothrium sp. 1A & Carcharhinus isodon & GQ470169 & Jensen and Bullard 2010 \\
\hline Anthobothrium sp. 1B & Carcharhinus limbatus & GQ470166 & Jensen and Bullard 2010 \\
\hline Anthobothrium sp. 1C & Rhizoprionodon terraenovae & GQ470161 & Jensen and Bullard 2010 \\
\hline Anthobothrium sp. $2 \mathrm{~A}$ & Carcharhinus isodon & GQ470160 & Jensen and Bullard 2010 \\
\hline Anthobothrium sp. 2B & Carcharhinus limbatus & GQ470159 & Jensen and Bullard 2010 \\
\hline Calyptrobothrium sp. & Apristurus laurussonii & AF382087 & Brickle et al. 2001 \\
\hline Ceratobothrium xanthocephalum Monticelli, 1892 & Isurus oxyrinchus & AF382089 & Brickle et al. 2001 \\
\hline Clistobothrium montaukense Ruhnke, 1993 & Isurus oxyrinchus & AF286957 & Olson et al. 2001 \\
\hline Crossobothrium longicolle (Molin, 1958) Euzet, 1959 & Scyliorhinus canicula & AF286958 & Olson et al. 2001 \\
\hline Marsupiobothrium sp. & Alopias pelagicus & AF286959 & Olson et al. 2001 \\
\hline Orygmatobothrium musteli (van Beneden, 1850) Diesing, 1863 & Mustelus asterias & AF382088 & Brickle et al. 2001 \\
\hline Paraorygmatobothrium sp. MS05-272-14* & Paralichthys lethostigma & GQ470008 & Jensen and Bullard 2010 \\
\hline Paraorygmatobothrium sp. MS05-34-15* & Trichiurus lepturus & GQ470022 & Jensen and Bullard 2010 \\
\hline Paraorygmatobothrium sp. MS05-292-8* & Opsanus beta & GQ470030 & Jensen and Bullard 2010 \\
\hline Paraorygmatobothrium sp. MS05-575-4* & Ariopsis felis & GQ470055 & Jensen and Bullard 2010 \\
\hline Paraorygmatobothrium sp. 2 & Rhizoprionodon terraenovae & GQ470021 & Jensen and Bullard 2010 \\
\hline Paraorygmatobothrium sp. 3A & Carcharhinus brevipinna & GQ470012 & Jensen and Bullard 2010 \\
\hline Paraorygmatobothrium sp. 3B & Carcharhinus limbatus & GQ470007 & Jensen and Bullard 2010 \\
\hline Paraorygmatobothrium sp. 3C & Rhizoprionodon terraenovae & GQ470006 & Jensen and Bullard 2010 \\
\hline Paraorygmatobothrium sp. 5A & Carcharhinus brevipinna & GQ470031 & Jensen and Bullard 2010 \\
\hline Paraorygmatobothrium sp. 5B & Carcharhinus isodon & GQ470038 & Jensen and Bullard 2010 \\
\hline Paraorygmatobothrium sp. 5C & Carcharhinus limbatus & GQ470036 & Jensen and Bullard 2010 \\
\hline Paraorygmatobothrium sp. 5D & Rhizoprionodon terraenovae & GQ470046 & Jensen and Bullard 2010 \\
\hline Paraorygmatobothrium sp. 6 & Carcharhinus brevipinna & GQ470004 & Jensen and Bullard 2010 \\
\hline Phyllobothrium lactuca van Beneden, 1850 & Mustelus asterias & AF286960 & Olson et al. 2001 \\
\hline \multicolumn{4}{|l|}{ Subfamily Thysanocephalinae Euzet, 1953} \\
\hline Thysanocephalum sp. & Galeocerdo cuvier & AF286963 & Olson et al. 2001 \\
\hline \multicolumn{4}{|l|}{ Subfamily not designated } \\
\hline Caulobothrium opisthorchis Riser, 1955 & Myliobatis californicus & FJ177106 & Healy et al. 2009 \\
\hline Caulobothrium sp. & Myliobatis californicus & FJ177101 & Healy et al. 2009 \\
\hline \multicolumn{4}{|l|}{ Family Serendipidae Brooks et Barriga, 1995} \\
\hline Duplicibothrium minutum Williams et Campbell, 1978 & Rhinoptera bonasus & GQ470136 & Jensen and Bullard 2010 \\
\hline Duplicibothrium sp. 1 & Rhinoptera bonasus & GQ470128 & Jensen and Bullard 2010 \\
\hline Duplicibothrium sp. $2 *$ & Solenosteira cancellaria & GQ470149 & Jensen and Bullard 2010 \\
\hline
\end{tabular}

* indicates sequences of larval metacestodes identified to genus by Jensen and Bullard (2010). 
able. Samples of substitution model parameters, and tree and branch lengths were summarised using the parameters 'sump burnin $=3000$ ' and 'sumt burnin $=3000$ '. These 'burnin' parameters were chosen because the log likelihood scores 'stabilised' well before 3,000,000 replicates in the Bayesian inference analyses.

Species of Lecanicephalidea were designated as the functional outgroups. Newly obtained sequences were added to GenBank (http://www.ncbi.nlm.nih.gov/Genbank/) under the accession numbers given in Table 1.

\section{RESULTS}

\section{Morphological results}

Hemipristicola gen. $\mathrm{n}$.

Diagnosis: Tetraphyllidea, Phyllobothriidae Braun, 1900, Phyllobothriinae Braun, 1900. Worms euapolytic. Scolex with four bothridia; each bothridium with deep central cavity and apical sucker. Proximal bothridial surfaces covered with serrate gladiate spinitriches, in which marginal serrations are restricted to distal half of spinithrix length; distal bothridial surface covered with aristate serrate gladiate spinitriches. Cephalic peduncle absent. Neck present; surface of neck and proglottids covered with scutes. Proglottids slightly craspedote, immature proglottids much wider than long. Subterminal proglottids mature, squarish to wider than long. Terminal proglottid longer than wide. Testes numerous, slightly oblong to round, two layers deep, post-vaginal testes present. Cirrus-sac reniform, curved anteriorly, containing coiled, armed cirrus. Genital pores lateral, alternating irregularly. Vagina opening anterior to cirrus-sac. Ovary near posterior end of proglottid, $\mathrm{H}$-shaped in dorsoventral view. Uterus ventral to vagina, median, extending anteriorly from anterior margin of ovary to well past level of cirrus-sac, reaching into anterior fifth of mature proglottids. Uterine duct present, entering anterior third of uterus. Vitellarium follicular, arranged in two lateral bands of follicles, extending almost entire length of mature proglottid, reduced at level of ovary and interrupted at level of cirrus-sac on poral side. Excretory ducts lateral. Parasites of Hemigaleidae. Type and only known species: Hemipristicola gunterae $\mathrm{sp} . \mathrm{n}$.

E t y m o log y: The genus name Hemipristicola is a compound of the stems Hemipristis (the host genus) and incola (Latin, noun: "an inhabitant"). Its gender is feminine.

Remarks. The new genus is consistent with the familial diagnosis of Phyllobothriidae Braun, 1900 given by Euzet (1994) and emended by McKenzie and Caira (1998). Hemipristicola lacks the scolex with a single, undivided, globular apical organ of Disculicipitidae Joyeux et Baer, 1936 and the four cup-shaped, glandular organs of Prosobothriidae Baer et Euzet, 1955, instead possessing a scolex consisting of four muscular bothridia. The bothridia of Hemipristicola are not subdivided by septa, like those of Serendipidae Brooks et Barriga, 1995, and lack the bothridial hooks of Onchobothriidae Braun, 1900. The proglottids of Hemipristicola are hermaphroditic, unlike the dioecious proglottids of Dioecotaeniidae Schmidt, 1969, and the vitellarium extends almost the entire length of the mature proglottid, rather than being confined to the posterior part of the proglottid, as in Chimaerocestidae Williams et Bray, 1984.

We place Hemipristicola in the Phyllobothriinae Braun, 1900. The new genus lacks the apical glandulomuscular myzorhynchus possessed by Echeneibothriinae de Beauchamp, 1905, lacks the characteristic metascolex of Thysanocephalinae Euzet, 1953, and lacks the bothridial loculi of Triloculariinae Yamaguti, 1959. Hemipristicola is completely consistent with the diagnosis of Phyllobothriinae given by Euzet (1994) and emended by McKenzie and Caira (1998).

In the most recent revision of the Phyllobothriidae, Ruhnke (2011) provisionally recognised 17 genera. The new taxon can be differentiated from these genera, and the newly erected Caulopatera Cutmore, Bennett et Cribb, 2010, as follows. The scolex of Hemipristicola lacks a metascolex, differentiating it from Thysanocephalum Linton, 1890. Hemipristicola possesses simple bothridium with a deep central cavity, which differentiates it from Bibursibothrium McKenzie et Caira, 1998, Marsupiobothrium Yamaguti, 1952 and Scyphophyllidium Woodland, 1927, which possess pouch-shaped bothridia, and from Doliobothrium Caira, Malek et Ruhnke, 2010, which possesses tubular bothridia. The bothridia of Hemipristicola lack a central sucker and are not separated by a cruciform apex, differentiating it from Clistobothrium Dailey et Vogelbein, 1990, and are not extremely foliose and distinctly bifid posteriorly, differentiating it from Phyllobothrium van Beneden, 1850. The new genus differs from Orygmatobothrium Diesing, 1863 in that the bothridia of Hemipristicola lack the prominent central, glandulomuscular organ of Orygmatobothrium. The bothridia of Hemipristicola do not possess marginal or medial bothridial loculi, differentiating it from Cardiobothrium McKenzie et Caira, 1998 and Ruhnkecestus Caira et Durkin, 2006, which both possess facial bothridial loculi, and Flexibothrium McKenzie et Caira, 1998, which possesses numerous marginal loculi. The bothridia of Hemipristicola possess a single, small apical sucker, differentiating it from Caulopatera, which lacks an apical sucker, and from Calyptrobothrium Monticelli, 1893, which have bothridia that possess a large anterior loculus that occupies at least a third of the bothridia. The vitellarium of Hemipristicola is arranged in two lateral bands of follicles, differentiating it from Monorygma Diesing, 1863 and Nandocestus Reyda, 2008, which possess a circum-medullary vitellarium. The proglottids of the new taxa are not laciniate, separating it from Crossobothrium Linton, 1889, and the vitellarium is reduced at the level of the ovary, further 
differentiating it from Crossobothrium, which has vitellarium that is extended at the level of the ovary.

Hemipristicola most closely resembles Orectolobicestus Ruhnke, Caira et Carpenter, 2006 and Paraorygmatobothrium Ruhnke, 1994, in that all three genera possess bothridia with a single loculus and apical sucker, a scutellate neck, post-vaginal testes and lateral vitellarium. The new genus, however, possesses a more extensive uterus, which extends anteriorly from the anterior margin of the ovary to well past the level of the cirrus-sac, reaching into the anterior fifth of mature proglottids. In comparison, the uterus of Paraorygmatobothrium and Orectolobicestus reaches only to the level of the cirrus-sac. Hemipristicola also differs from both Paraorygmatobothrium and Orectolobicestus in the morphology of the proximal bothridial surface microthrix. Although all three genera possess serrate gladiate spinitriches on the proximal bothridial surface, Hemipristicola possesses serrate gladiate spinitriches with marginal serrations restricted to the distal half of the blade. In comparison, species of Paraorygmatobothrium and Orectolobicestus possess serrate gladiate spinitriches with marginal serrations along almost the entire length of the blade on the proximal bothridial surface. Hemipristicola also possesses testes that are more than one layer deep, compared to only a single layer deep for both Paraorygmatobothrium and Orectolobicestus. Hemipristicola further differs from Orectolobicestus in lacking the distinctive bothridial marginal loculi and in possessing a vitellarium that is reduced, rather than completely interrupted, at the level of the ovary. The new genus also resembles Orygmatobothrium to some extent, in possessing bothridia with a single loculus and apical sucker and a strongly, anteriorly curved cirrus-sac. Of the three valid Orygmatobothrium species, Hemipristicola further resembles Orygmatobothrium schmittii Suriano et Labriola, 2001 in having testes that are more than one layer deep, with the new taxon having testes two to three layers deep and $O$. schmittii having testes three rows deep in cross-section (Ivanov 2008). In addition to the lack the prominent central, glandulomuscular organ of Orygmatobothrium, the new genus further differs from Orygmatobothrium in that it lacks a cephalic peduncle and possesses a uterus that extends much further anteriorly than that of species of Orygmatobothrium.

\section{Hemipristicola gunterae sp. $\mathrm{n}$.}

Figs. 1-2

Description. Based on 3 whole-mounts of mature specimens, 6 whole-mounts of immature specimens and 4 specimens for SEM. Worms euapolytic, $58.2(\mathrm{n}=1) \mathrm{mm}$ long; maximum width $1222(\mathrm{n}=1)$, at level of immature proglottids in middle third of strobila. Scolex tetrabothridiate (Figs. 1B, 2A), 629-833 (739 $\pm 70 ; n=9)$ long, 918-1102 $(1005 \pm 66 ; \mathrm{n}=9)$ wide. Bothridia 581-833 (704 $\pm 63 ; \mathrm{n}=9 ; n=17)$ long, 425-621 (494 $\pm 59 ; \mathrm{n}=9$; $n=17$ ) wide, with single loculus, deep central cavity and single apical sucker (Fig. 2D). Apical sucker 90-118
$(104 \pm 7 ; \mathrm{n}=9 ; n=22)$ in diameter. Proximal bothridial surfaces covered with serrate gladiate spinitriches, in which marginal serrations are restricted to distal half of spinithrix length, and capilliform filitriches (Fig. 2B). Distal bothridial surface covered with aristate serrate gladiate spinitriches and capilliform filitriches (Fig. 2C, E). Cephalic peduncle absent. Neck present, 15.3-16.9 $(16.4 \pm 0.9 ; \mathrm{n}=3) \mathrm{mm}$ long; surface of neck and strobila covered with scutes; neck and strobilar scutes consist of densely packed filitriches.

Proglottids slightly craspedote, $340(n=1)$ in number. Immature proglottids much wider than long. Subterminal proglottids mature, squarish to wider than long, 477-983 $(676 \pm 139 ; \mathrm{n}=3 ; n=15)$ long, 893-1146 (1027 \pm 76 ; $\mathrm{n}=3 ; n=15)$ wide; length to width ratio $0.43-1.10: 1$ $(0.67 \pm 0.19 ; \mathrm{n}=3 ; n=15)$. Terminal proglottid longer than wide (Fig. 1D), 1144-1378 (1233 $\pm 126 ; \mathrm{n}=3)$ long, $817-901(869 \pm 45 ; \mathrm{n}=3)$ wide; length to width ratio $1.27-1.69: 1(1.43 \pm 0.23 ; \mathrm{n}=3)$. Testes slightly oblong to round, $172-191(181 \pm 10 ; n=3)$ in number in terminal proglottid, two to three layers deep, 55-79 (68 \pm 5 ; $\mathrm{n}=3 ; n=27)$ long, 50-66 (60 $\pm 4 ; \mathrm{n}=3 ; n=27)$ wide; length to width ratio $1-1.36: 1(1.14 \pm 0.09 ; \mathrm{n}=3 ; n=27)$. Cirrus-sac elongate reniform, curving anteriorly, contains coiled cirrus, 392-416 (406 $\pm 12 ; n=3)$ long, 138-143 $(140 \pm 3 ; \mathrm{n}=3)$ wide; length to width ratio $2.74-3.02: 1$ $(2.90 \pm 0.14 ; \mathrm{n}=3)$. Cirrus armed with small microtriches. Vas deferens coiled, anterior to and bordering proximal portion of cirrus-sac, extending almost to anterior margin of uterus. Vagina extending anteriorly from genital atrium along anterior cirrus-sac margin and margin of vas deferens to mid-line of proglottid, extending anteriorly to approximately level with anterior margin of uterus, then posteriorly along mid-line of proglottid to ovary. Genital atrium shallow. Genital pores lateral, alternating irregularly, $57-59 \%(58 \pm 1 ; \mathrm{n}=3)$ of proglottid length from posterior end of proglottid. Ovary near posterior end of proglottid, lobulate, H-shaped in dorsoventral view, 287$317(302 \pm 15 ; \mathrm{n}=3)$ long, 420-516 (457 $\pm 52 ; \mathrm{n}=3)$ wide. Ovicapt at posterior margin of ovarian bridge. Mehlis' gland posterior to ovicapt, between posterior half of ovarian lobes, 112-123 (116 $\pm 6 ; n=3)$ long, 94-103 $(99 \pm 5 ; n=3)$ wide. Vitellarium follicular, arranged in 2 lateral bands of follicles, extending almost entire length of mature proglottid, reduced at level of ovary and interrupted both dorsally and ventrally at level of cirrus-sac on poral side. Uterus ventral to vagina, median, extends anteriorly from anterior margin of ovary to well past level of cirrus-sac, reaching into anterior fifth of mature proglottids (Fig. 1C). Uterine duct dorsal to uterus, median, extends anteriorly, entering anterior third of uterus. Eggs not seen. Excretory ducts lateral.

Type host: Hemipristis elongata (Klunzinger) (Carcharhiniformes: Hemigaleidae), snaggletooth shark.

Type locality: Wynnum banks $\left(27^{\circ} 25^{\prime} \mathrm{S} ; 153^{\circ} 10^{\prime} \mathrm{E}\right)$, Moreton Bay, Queensland, Australia. 


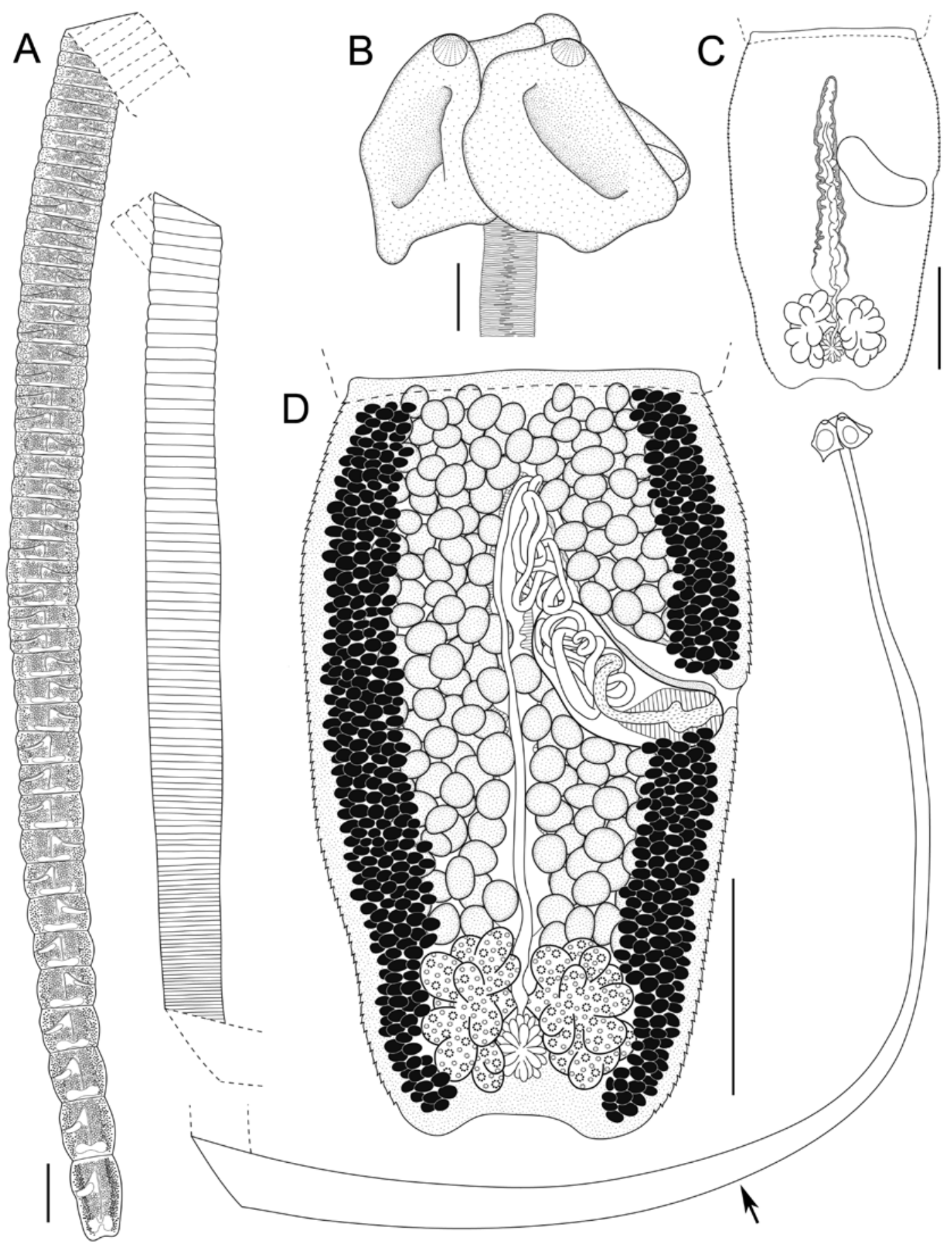

Fig. 1. Hemipristicola gunterae gen. n., sp. n. (holotype QM G 232173), line drawings. A - whole worm (black arrow indicates boundary between neck and strobila); $\mathbf{B}$ - scolex; $\mathbf{C}$ - terminal proglottid with testes and vitelline follicles removed to highlight position of uterus and uterine duct; $\mathbf{D}$ - terminal proglottid, dorsal view (note: uterine duct not illustrated). Scale bars: $\mathrm{A}=1 \mathrm{~mm}$; $\mathrm{B}=200 \mu \mathrm{m} ; \mathrm{C}, \mathrm{D}=400 \mu \mathrm{m}$.

Site of infection: Spiral intestine.

Prevalence: 2 of 2 .

Type materia 1: Holotype (QM G 232173) and 8 paratypes (QM G 232174-81) deposited in the Queensland Museum, Brisbane, Australia.
Molecular sequence data: 28S rDNA, 3 identical replicates (hologenophores QM G 232174-5 and QM G 232181) (GenBank Acc. No. HQ680622-4).

E t y m o log y: This species is named for Dr. Nicole Gunter in appreciation of her continual advice and substantial contribution to the knowledge of Australian marine parasites. 


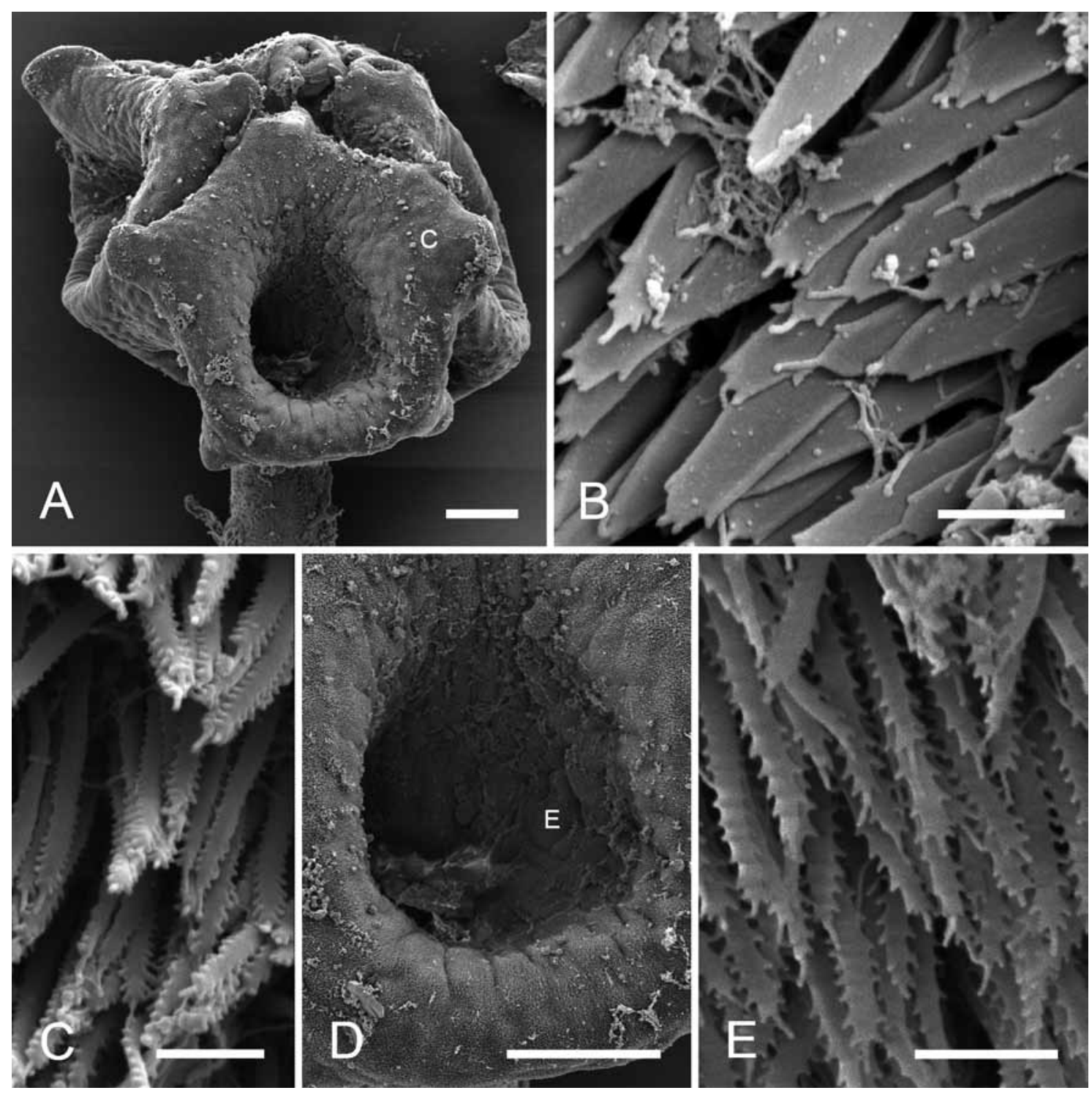

Fig. 2. Hemipristicola gunterae gen. n., sp. n., scanning electron micrographs. A - scolex (letter indicates where $\mathrm{C}$ was taken); B - proximal bothridial surface; C - distal bothridial surface; D - bothridial cavity (letter indicates where E was taken); $\mathbf{E}-$ distal bothridial surface in centre of bothridial cavity. Scale bars: A, D = $100 \mu \mathrm{m} ; \mathrm{B}, \mathrm{C}, \mathrm{E}=1 \mu \mathrm{m}$.

\section{Molecular results}

Alignment of the partial 28S rDNA region for Hemipristicola gunterae and the remainder of the cestode taxa examined yielded 1144 characters for analysis. No intraspecific variation was observed in three replicates of $H$. gunterae sequenced over the partial LSU rDNA region. Bayesian inference analysis of the LSU rDNA dataset resulted in a phylogram in which $H$. gunterae formed a strongly supported clade sister to species of Paraorygmatobothrium (Fig. 3). Most of the genera included in this analysis were resolved with high posterior probability support. Two exceptions were that two species of Rhinebothrium Linton, 1890 were paraphyletic relative to species of Rhabdotobothrium Euzet, 1953, Rhodobothrium Linton, 1889 and Spongiobothrium Linton, 1889 and the Marsupiobothrium sp. grouped within Paraorygmatobothrium. Relationships between many of the tetraphyllidean genera remain unresolved in this analysis as indicated by the presence of two major polytomies.

\section{DISCUSSION}

In deciding to propose a new genus to accommodate the new species from $H$. elongata, both morphological and molecular data were influential. Hemipristicola gunterae possesses morphological features characteristic of several phyllobothriid genera (e.g. Paraorygmatobothrium, Orectolobicestus and Orygmatobothrium). Although similar in proglottid morphology to some Orygmatobothrium species, H. gunterae is most similar to Paraorygmatobothrium, due to the possession of bothridia with a single 


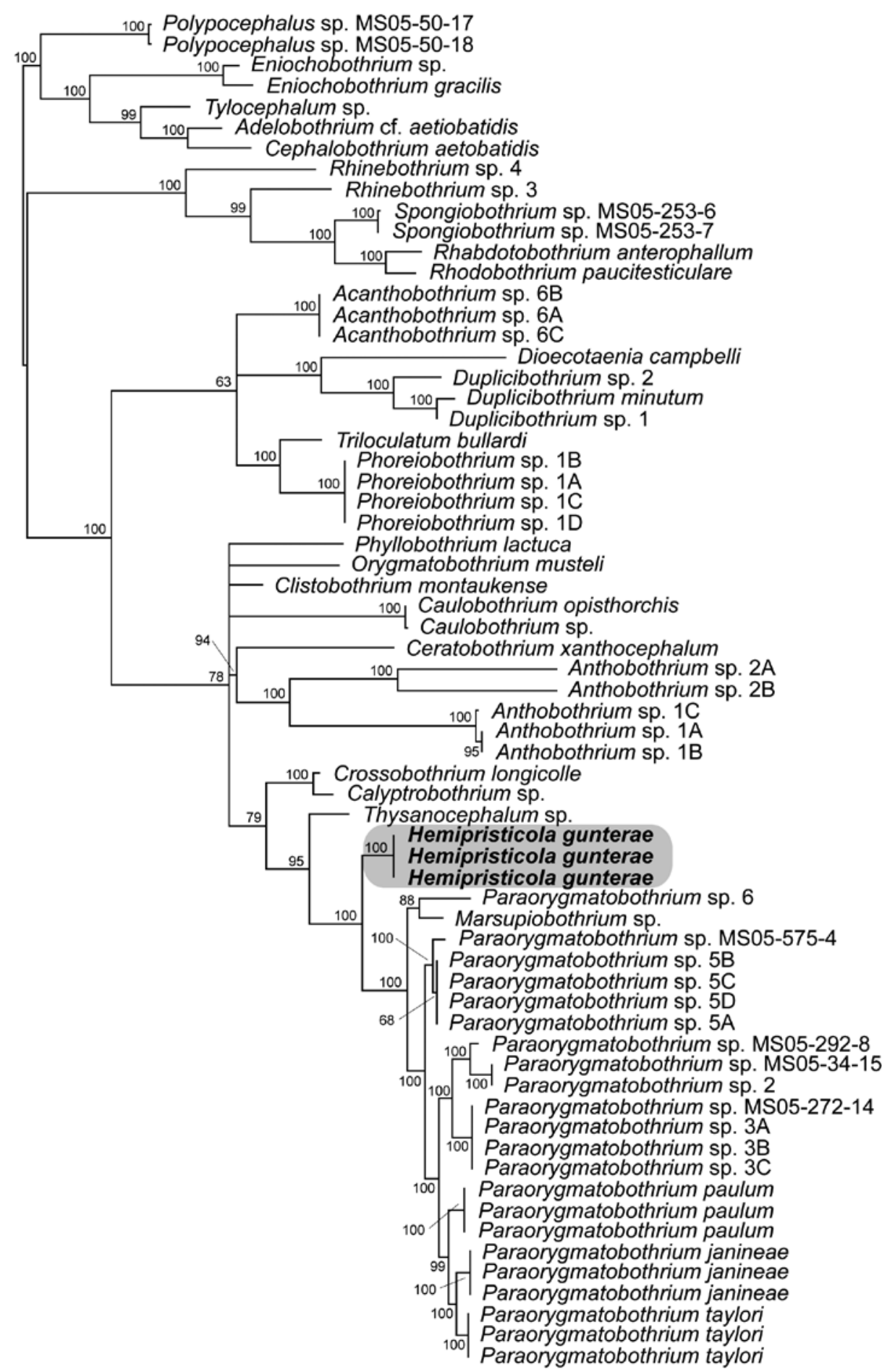

-10 changes

Fig. 3. Relationships between Hemipristicola gunterae gen. n., sp. n. and related cestode taxa based on Bayesian inference analysis of the partial $28 \mathrm{~S}$ rDNA dataset. Posterior probabilities are shown at the nodes with values $<50$ not shown.

loculus and apical sucker, a scutellate neck, post-vaginal testes and lateral vitellarium. However, the new taxon differs from Paraorygmatobothrium species in several distinctive characteristics (e.g. uterus morphology, micro- thrix morphology, testes placement), which are discussed in the differential diagnosis of the genus. In addition to these morphological features, the new taxon further differs from Paraorygmatobothrium species described from 
hemigaleid sharks which possess features that differ from the majority of Paraorygmatobothrium species. The three Paraorygmatobothrium species previously described from hemigaleid sharks ( $P$. janineae, $P$. kirstenae Ruhnke, Healy et Shapero, 2006 and $P$. taylori Cutmore, Bennett et Cribb, 2009) all possess a cephalic peduncle and vitelline follicles that extend almost to the mid-line of the proglottid (Ruhnke et al. 2006a, Cutmore et al. 2009). Hemipristicola gunterae further differs from these species in that it possesses vitelline follicles arranged in two lateral bands that are restricted to the lateral margins of the proglottid and it does not possess a cephalic peduncle.

Molecular analysis provided further support for the proposal of Hemipristicola, in that Bayesian inference analysis of the LSU rDNA dataset shows that multiple species of Paraorygmatobothrium form a strongly supported clade to the exclusion of $H$. gunterae (Fig. 3). The Paraorygmatobothrium clade included two Paraorygmatobothrium species from hemigaleid sharks of Moreton Bay (P.janineae and P. taylori). These two species formed a strongly supported clade within the larger Paraorygmatobothrium clade, further supporting the distinction between the new taxon and the Paraorygmatobothrium species of hemigaleids. The grouping of the single Marsupiobothrium species within the Paraorygmatobothrium clade (also noted by Jensen and Bullard 2010) is intriguing; although more molecular data for Marsupiobothrium are needed for this issue to be fully addressed, it seems possible that this specimen was misidentified.

Subfamilial relationships within the Phyllobothriidae are poorly resolved, with Thysanocephalum sp. (subfamily Thysanocephalinae) nesting within the clade consisting of the phyllobothriine genera Calyptrobothrium, Crossobothrium, Hemipristicola and Paraorygmatobothrium. In this analysis Caulobothrium Baer, 1948 grouped within the tetraphyllidean clade, supporting the decision by Healy et al. (2009) to not include it in the newly erected Rhinebothriidea.

The new species possesses several interesting morphological features that are worthy of discussion. Like most species of Paraorygmatobothrium, Orectolobicestus and Ruhnkecestus latipi Caira et Durkin, 2006, Hemipristicola gunterae possesses serrate gladiate spinitriches on the proximal bothridial surfaces. However, the serrate gladiate spinitriches of $H$. gunterae are distinctive in that the marginal serrations are restricted to the distal half of the blade, compared to almost the entire length of the blade on the proximal bothridial surface of Paraorygmatobothrium, Orectolobicestus and $R$. latipi (Ruhnke 2011). The spinitriches are also not nearly as uniformly serrated as those found on most species of Paraorygmatobothrium, Orectolobicestus and R. latipi (e.g. Caira and Durkin 2006, Ruhnke et al. 2006a, b, Ruhnke and Carpenter 2008, Malek et al. 2010). The spinitriches of $H$. gunterae are most similar to those found on the proximal bothridial surface of Orectolobicestus mukahensis Ruhnke, Caira et Carpenter, 2006, which also has the marginal serrations restricted to the distal half of spinithrix length and also appear to be less uniformly serrated (Ruhnke et al. 2006b). Another novel bothridial feature of the new genus is the central bothridial cavity. This cavity, however, is merely a pronounced depression, and does not create sac-like bothridia like those of Guidus Ivanov, 2006 and Marsupiobothrium, pouch-shaped bothridia like those of Bibursibothrium and Scyphophyllidium, or tubular bothridia like those of Doliobothrium Caira, Malek et Ruhnke, 2010 and Pithophorus Southwell, 1925. A similar central bothridial cavity was reported from $P$. taylori, but the bothridial cavity of $P$. taylori differs in that it is surrounded by semicircular bothridial muscle bands (Cutmore et al. 2009), which $H$. gunterae does not possess. Finally, the uterus of $H$. gunterae extends particularly far anteriorly in mature, non-gravid proglottids, extending well past the level of the cirrus-sac and genital pore, reaching into the anterior fifth of the proglottid. This contrasts with most phyllobothriine genera, in which the uterus generally only reaches anteriorly to the level of the cirrus-sac in mature proglottids (Ruhnke 2011).

Hemipristicola is currently known only from the typelocality, Moreton Bay, in south-east Queensland, Australia. However, it seems unlikely that the genus will be so geographically restricted. Hemipristis elongata is widespread in Australian waters, being found along the entire northern coastline, from Moreton Bay on the eastern coast to Bunbury on the western coast, and it is found throughout the tropical Indo-west Pacific (Compagno et al. 2005, Last and Stevens 2009). Hemipristicola gunter$a e$, or potentially new species of this genus, may be found throughout this extensive range, as helminthological analysis of this highly vagile shark has been limited, at least throughout much of its Australian distribution. Notably, a wide geographical distribution has been found previously for another phyllobothriid species from $H$. elongata. Cutmore et al. (2009) recorded P. janineae from Moreton Bay, approximately $4,000 \mathrm{~km}$ from its type locality in the Northern Territory.

There are a further seven species of hemigaleids described worldwide, six of which are found in the Indowest Pacific and one in the east Atlantic (Compagno et al. 2005). With the exception of species of Hemigaleus Bleeker, the phyllobothriid fauna of hemigaleid sharks is virtually unknown and we predict that further examination of these sharks will yield new species of Hemipristicola. Specimens recorded by Southwell (1927) as "Phyllobothrium tumidum Linton 1922" from Hemigaleus balfouri [now synonymised with Chaenogaleus macrostoma (Bleeker)] broadly agree with the diagnosis of Hemipristicola in scolex and immature proglottid morphology. The specimens, however, are broken along the strobilar length and no mature terminal proglottids were available for examination. We suspect that these specimens represent a second species of this genus but definitive identifi- 
cation is not possible without fresh collection of this form. The description of Hemipristicola, along with the recent descriptions of Orectolobicestus, Caulopatera and Doliobothrium, illustrates the current gap in the knowledge of phyllobothriids of many Australian sharks and highlights the potential for the discovery of new and interesting tetraphyllidean taxa in the vast array of elasmobranchs found in Australian waters.
Acknowledgements. We thank John Page, Dr. Stephen Taylor, Dr. Nathan Hart and Dr. Jeremy F.P. Ullmann for their assistance in the collection of elasmobranch specimens, Dr. Terrence Miller for assistance with phylogenetic analysis and Dr. Rod Bray and Eileen Harris of the Natural History Museum, London, for assistance with examining specimens from "Hemigaleus balfouri". We also thank the Tangalooma Wild Dolphin Resort for support of a broader project to $\mathrm{MBB}$, of which this was a part.

\section{REFERENCES}

Brickle P., Olson P.D., Littlewood D.T.J., Bishop A., ArkhipKIN A.I. 2001: Parasites of Loligo gahi from waters off the Falkland Islands, with a phylogenetically based identification of their cestode larvae. Can. J. Zool. 79: 2289-2296.

Caira J.N., Durkin S.M. 2006: A new genus and species of Tetraphyllidean cestode from the spadenose shark, Scoliodon laticaudus, in Malaysian Borneo. Comp. Parasitol. 73: 42-48.

Caira J.N., Reyda F.B., Mega J.D. 2007: A revision of Megalonchos Baer \& Euzet, 1962 (Tetraphyllidea: Onchobothriidae), with the description of two new species and transfer of two species to Biloculuncus Nasin, Caira \& Euzet, 1997. Syst. Parasitol. 67: 211-223.

Chervy L. 2009: Unified terminology for cestode microtriches: a proposal from the International Workshops on Cestode Systematics in 2002-2008. Folia Parasitol. 56: 199-230.

Compagno L., Dando M., Fowler S. 2005: A Field Guide to the Sharks of the World. Collins, London, $368 \mathrm{pp.}$

Cutmore S.C., Bennett M.B., Cribi T.H. 2009: Paraorygmatobothrium taylori n. sp. (Tetraphyllidea: Phyllobothriidae) from the Australian weasel shark Hemigaleus australiensis White, Last \& Compagno (Carcharhiniformes: Hemigaleidae). Syst. Parasitol. 74: 49-58.

EdGAR R.C. 2004: MUSCLE: multiple sequence alignment with high accuracy and high throughput. Nucleic Acids Res. 32: 1792-1797.

Euzet L. 1994: Order Tetraphyllidea Carus, 1863. In: L.F. Khalil, A. Jones and R.A. Bray (Eds.), Keys to the Cestode Parasites of Vertebrates. CAB International, Wallingford, pp. 149-194.

Guindon S., Gascuel O. 2003: A simple, fast, and accurate algorithm to estimate large phylogenies by maximum likelihood. Syst. Biol. 52: 696-704.

Healy C.J., Caira J.N., Jensen K., Webster B.L., Littlewood D.T.J. 2009: Proposal for a new tapeworm order, Rhinebothriidea. Int. J. Parasitol. 39: 497-511.

Ivanov V.A. 2008: Orygmatobothrium spp. (Cestoda: Tetraphyllidea) from triakid sharks in Argentina: redescription of Orygmatobothrium schmittii and description of a new species. J. Parasitol. 94: 1087-1097.

Jensen K., Bullard S.A. 2010: Characterization of a diversity of tetraphyllidean and rhinebothriidean cestode larval types, with comments on host associations and life-cycles. Int. J. Parasitol. 40: 889-910.

Last P.R., Stevens J.D. 2009: Sharks and Rays of Australia. CSIRO Publishing, Collingwood, 644 pp.

Littlewood D.T.J., Curini-Galletti M., Herniou E.A. 2000: The interrelationships of Proseriata (Platyhelminthes: Seriata) tested with molecules and morphology. Mol. Phylogenet. Evol. 16: $449-466$.
Maddison W.P., Maddison D.R. 2009: Mesquite: a modular system for evolutionary analysis. Version $2.72 \mathrm{http}$ ://mesquiteproject.org.

Malek M., Caira J.N., Haseli M. 2010: Two new species of Paraorygmatobothrium Ruhnke, 1994 (Cestoda: Tetraphyllidea) from the carcharhinid shark Carcharhinus cf. dussumieri (Müller \& Henle) in the Persian Gulf. Syst. Parasitol. 76: 59-68.

McKenzie V.J., Caira J.N. 1998: Three new genera and species of tapeworms from the longnose sawshark, Pristiophorus cirratus, with comments on their modes of attachment to the spiral intestine. J. Parasitol. 84: 409-421.

Miller M.A., Holder M.T., Vos R., Midford P.E., Liebowitz T., Chan L., Hoover P., Warnow T. 2009: The CIPRES Portals. CIPRES. 2009-08-04. URL:http://www.phylo.org/ sub_sections/portal. Accessed: 2009-08-04. (Archived by WebCite(r) at http://www.webcitation.org/5imQ1JeQa).

Olson P.D., Littlewood D.T.J., Bray R.A., Mariaux J. 2001: Interrelationships and evolution of the tapeworms (Platyhelminthes: Cestoda). Mol. Phylogenet. Evol. 19: 443-467.

PosadA D. 2008: jModelTest: Phylogenetic Model Averaging. Mol. Biol. Evol. 25: 1253-1256.

Ronquist F., Huelsenbeck J.P. 2003: MRBAYES 3: Bayesian phylogenetic inference under mixed models. Bioinformatics 19: $1572-1574$.

Ruhnke T.R. 2011: Tapeworms of elasmobranchs (Part III). A monograph on the Phyllobothriidae (Platyhelminthes, Cestoda). Bull. Univ. Nebr. State Mus. 25: i-xii, 1-208.

Ruhnke T.R., Caira J.N., Carpenter S.D. 2006b: Orectolobicestus $\mathrm{n}$. g. (Cestoda: Tetraphyllidea), with the description of five new species and the transfer of Phyllobothrium chiloscyllii to the new genus. Syst. Parasitol. 65: 215-233.

Ruhnke T.R., Carpenter S.D. 2008: Two new species of Paraorygmatobothrium Ruhnke, 1994 (Tetraphyllidea: Phyllobothriidae) from the smooth-hound Mustelus mustelus (L.) and the gummy shark $M$. antarcticus Günther (Carcharhiniformes: Triakidae). Syst. Parasitol. 71: 213-222.

Ruhnke T.R., Healy C.J., Shapero S. 2006a: Two new species of Paraorygmatobothrium (Cestoda: Tetraphyllidea) from weasel sharks (Carcharhiniformes: Hemigaleidae) of Australia and Borneo. J. Parasitol. 92: 145-150.

Sambrook J., Russell D.W. 2001: Molecular Cloning: A Laboratory Manual. Cold Spring Harbor Laboratory Press, Cold Spring Harbor, New York.

Southwell T. 1927: On a collection of cestodes from marine fishes of Ceylon and India. Ann. Trop. Med. Parasitol. 21: 351-373.

Waeschenbach A., Webster B.L., Bray R.A., Littlewood D.T.J. 2007: Added resolution among ordinal level relationships of tapeworms (Platyhelminthes: Cestoda) with complete small and large subunit nuclear ribosomal RNA genes. Mol. Phylogenet. Evol. 45: 311-325. 